\title{
Crisis Management on Education Policies during Covid-19: The Case of China, USA and Italy
}

\author{
DOI: $10.26466 /$ opus.826383
}

\author{
$*$ \\ İsmail Karsant1k* \\ * Dr., Recep Tayyip Erdoğan University, Faculty of Education, Rize/Turkey \\ E-Mail: ismailkarsantik@gmail.com \\ ORCID: 0000-0002-0279-7397
}

\begin{abstract}
COVID-19 is a global pandemic and affects countries in several dimensions such as health system, economy and education. The current study seeks to report and compare implementations of educational policy during COVID-19 pandemic in China, USA and Italy within the framework of crisis management process. The current study is descriptive in that it seeks to document sources on the phenomenon COVID-19 pandemic and explore similar or different implementations of educational policies. The findings indicate that educational policies are implemented in mostly similar patterns except slight differences in administrative approaches. Although the outcomes of the policies will be evident in the future, some implications can be listed as flexible and systematic planning of educational policies, collaboration and cooperation among authorities and schools, improving internet infrastructure and providing flexible educational programs. It is expected that investigation of educational policies and implementations in pandemic will guide in terms of managing crisis in educational issues.
\end{abstract}

Keywords: Covid-19, coronavirus, educational policy, educational management, crisis management 
ISSN:2528-9527

E-ISSN : 2528-9535

YIl Year: 11

Cilt Volume: 17

Sayı Issue :Pandemi Özel Sayısı

Nisan April 2021

\section{Kriz Yönetimi Bağlamında Covid-19'un Eğitim Politikalarına Etkisi: Çin, ABD ve İtalya Örneği}

$\ddot{O} z$

Küresel bir salgin olan COVID-19, ülkeleri; sağllk sistemi, ekonomi ve eğitim gibi çeşitli boyutlarda etkilemektedir. Mevcut çalışma, kriz yönetimi süreci çerçevesinde Çin, ABD ve İtalya'da COVID-19 salgını sırasında eğitim politikası uygulamalarım rapor etmeyi ve karşılaştırmayı amaçlamaktadır. Betimleyici nitelikte hazırlanan bu çalısma, COVID-19 fenomeni hakkındaki kaynakları belgelemeye ve eğitim politikalarının benzer ve farklı uygulamalarım keşfetmeyi amaçlamaktadır. Bulgular, eğitim politikalarının, idari yaklaşımlardaki küçük farklılıklar dışında çoğunlukla benzer modellerde uygulandığını göstermektedir. Araştırma bulguları belirtilen ülkelerdeki eğitim alanında uygulanan hazırlıkları; eğitim politikalarının esnek ve sistematik planlanması, yetkililer ve okullar arasındaki işbirliği ve koordinasyon, internet altyapısının iyileştirilmesi ve esnek eğitim programlarının sağlanması olarak sıralanmaktadır. Pandemide eğitim politikaları ve uygulamalarının araştırılmasının eğitim konularında kriz yönetimi açısından yol gösterici olması beklenmektedir.

Anahtar Kelimeler: Kovid-19, koronavirüs, eğitim politikası, eğitim yönetimi, kriz yönetimi 


\section{Introduction}

COVID-19 (Coronavirus) was first detected in Wuhan city, China. On 30th January 2020, Public Health Emergency of International Concern is declared by the World Health Organization (WHO). Since then, a rising awareness has been witnessed by the public and governments in 135 countries. Business, health organizations, tourism, and education are affected by the outbreak of COVID-19. Except for Antarctica, COVID-19 has been detected in all continents by 26 February 2020 (McAleer, 2020). A record number of students, youth, and older people are trying to continue their interrupted life according to the measures taken by authorities. Beside social isolation, there are many other measures taken by countries to manage risks. One of the fields that the measures are implemented is education. To prevent a potential disaster and gathering people around, schools are quarantined temporarily by the government officials. For instance, in China, more that 180 million students are having distance education using online courses through technological advancements. In Central Asia, Europe and USA, primary, secondary, and tertiary education systems are being maintained simultaneously by online classes and e-sources. (Patrinos and Shmis, 2020).

Enhancing preparedness of educational context toward pandemic situations is also seen as a test for organizational agility. Adaptation to the current pandemic needs innovative creations covering teaching and research activities. Strategic, holistic, practical thinking beside coordination of internal and external stakeholders is thought to be one the outcomes of COVID19 pandemic (Zhaohui, 2020). In the current study, educational strategies followed by China, USA and Italy during COVID-19 are investigated. The reasons why those countries are selected are that they are located in different continents and they have been considerably affected by the pandemic. To this end, the current study seeks to report and compare initial implementations of educational policy in early stages of COVID-19 pandemic in China, USA and Italy within the framework of crisis management process proposed by Pearson and Clair (1998). The study is important for at least two reasons. First, examining political and strategic implementations in pandemic situation is expected to guide other countries in terms of managing crisis in educational issues. Second, there is a gap in literature in terms 
of addressing the effects of pandemic on educational policies and implementations. Therefore, the results of the study are expected to contribute to literature in terms of providing an overview on crisis management in educational issues during pandemic and suggesting practical and research implications.

\section{Crisis Management Process}

Pearson and Clair (1998) define crisis management as "a systematic attempt by organizational members with external stakeholders to avert crises or to effectively manage those that do occur." (p. 61). Crisis management process is categorized under psychological, social-political, and technological structural perspectives and Figure 1 displays the crisis management process (Pearson and Clair, 1998).

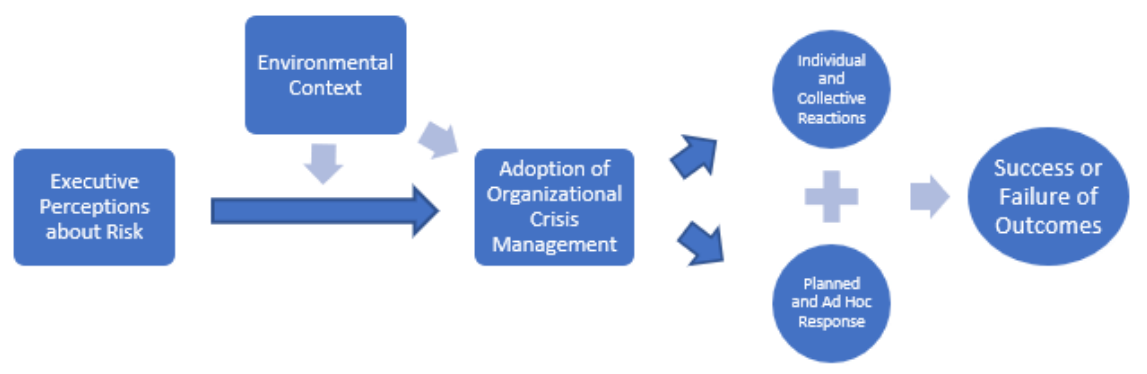

Figure 1. The Crisis Management Process (Pearson and Clair, 1998)

As indicated in the Figure 1, crisis management is a multidimensional process. Environmental context involves institutionalized practices and industry regulations which affects concern for or attention to crisis preparations. Those preparations influence adoption of organizational crisis management. Environmental context, executive perceptions and crisis management preparations lead to individual-collective reactions and planned-ad hoc responses. Individual and collective reactions include shattered assumption, impaired cognitive, emotional and behavioral responses, and eroded social structure. Those reactions have a two-way relationship with planned and ad hoc responses, which include team vs. individual response, alliance-coordination of stakeholders, information dissemination, organization-industry visibility. Finally, those variables lead to outcomes with either success or failure in crisis management (Pearson and Clair, 1998). 


\section{Method}

The current review study is conducted within the framework of qualitative method. Review method is suitable to create a synthesis from the ideas and approaches of existing studies and to contribute to the summary of these ideas and approaches (Herdman, 2006). In the current study, the information obtained is compiled under the headings of educational policy implementations following crisis management stages (Pearson and Clair, 1998) and presented in a comprehensive integrity.

\section{Findings}

\section{Educational policy implementations in China}

The first country hit by COVID-19 (which is indicated as a new type of coronavirus 2019-nCoV) outbreak is China. Wuhan Municipal Health Commission published a report implicating 27 cases in Wuhan (Wuhan Municipal Health Commission, 2019). Turning into a national crisis, the number of people infected by the COVID-19 has risen in a month (Liu and Saif, 2020). Turning into a global crisis, people are started to be searched about their travel and contact history regarding Wuhan territory to prevent an outbreak (Yue et al., 2020). Although screening procedures continue, life in $\mathrm{Wu}$ han district started to return normal after two months of lockdown. Transportation, business, trade and tourism as well as education is getting back to normal in China (Reuters, 2020). Therefore, careful consideration is needed to understand gains and losses of the strategies implemented in education during COVID-19 outbreak.

In terms of educational policies, Suspending Classes Without Stopping Learning policy is implemented by Chinese government officials to start and increase online education instead of face-to-face education (Zhang et al., 2020). By implementation of the policy, Ministry of Education states that learning and teaching activities will suspend in China throughout the pandemic. National and local integration of educational sources and providing diverse and high-quality e-sources for students are the main objective for carrying out the policy (Ministry of Education of the People's Republic of China, 2020a). 
Online education procedures continually require feedbacks and adjustments during implementation of policy. Adjustable strategies have been applied by Chinese government in an orderly manner to implement the policy. According to Zhang et al. (2020) strategies are implemented through five stages:

1. One of the first priorities of the policy implementation is to integrate national resources and to plan at the top-level. Online education needs a stable internet connection. To ensure that, the Ministry of Education and internet providers such as China Education and Scientific Research Computer Network, China Mobile, and China Satellite Communication worked together to maintain internet for purpose of public and education.

2. Teachers receive in-service education for online teaching strategies organized by the education administration department of the Ministry of Education and teacher training companies. Through the education, teachers receive information about online teaching strategies, applications, school epidemic prevention cases, local teacher training cases and so forth. Moreover, teachers are encouraged and make reflective learning by a feedback system summarizing and sharing experiences of teachers and debating on it.

3. To fix the time imbalance, Chinese government carry out online teaching in different regions of country without internet connection by satellite TVs (Ministry of Education of the People's Republic of China, $2020 b$ ). Duration of classes are arranged by local government for each education level: one hour for lower grades of primary school, two hours for higher grades of primary school, four hours for middle school, and five hours for high school (The People's Government of Zhejiang Province, 2020).

4. After the epidemic, transition to face-to-face education may need a guideline. In that stage, teachers are encouraged to teach in an independent way using the National Elite Online Open Courses as examples.

5. For the smooth transition after the pandemic, based on regional and national variables, Ministry of Education takes characteristics of students such as preparedness, population, and age into account. Moreo- 
ver, Chinese government takes screening precautions to prevent a potential re-outbreak. In this manner quarantine for all international arrivals, travel and medical history of people are searched.

To strengthen organization and management capabilities of administration, the leading group in Ministry of Education requested to be supported by local authorities and higher education institutions for implementing supportive and proactive measures and planning. These plans include several items (Education and Technology Department, 2020):

1. Implementing the plan requires resource provision, technical stability, content review, training guidance, effective supervision. Besides, local authorities are required to be in coordination with communication departments and operators.

2. Technical support is also another item that needs attention. Since schools and higher education institutions conduct online teaching, they need to be provided with actual needs, resources and online platforms. Monitoring is the second stage regarding technical support. To ensure a safe and stable internet connection, primary and secondary schools are monitored and required to give report to educational administration department in charge.

3. To ensure the quality of online education, it is necessary to give feedback to educational administration department. For a smooth transition to face-to-face education, awareness toward epidemic situation should be considered during online education programs. Teachers should formulate online education guidelines to make full use of online resources.

4. Scientific implementation procedures should be followed during teaching progress, arranging workload and assessment and evaluation stages. Online education implementation should take less time comparing with the office hours. Number and duration of break times should also be extended.

In terms of making available online education platforms, China's education system has been adapted to COVID-19 rapidly and remarkably. Ministry of Education provide online education platform with 50 million connection of learners and teachers simultaneously. In this manner, China managed to affiliate partnerships between private organizations, local authorities and general public, national authorities (UNESCO, 2020). 


\section{Educational policy implementations in USA}

U.S. Centers for Disease Control and Prevention (CDC) affirmed a growing number of infections in countries including USA. Different geographic areas of USA have different levels of COVID-19 infection activity (OSHA, 2020). CDC confirmed the first case in USA on 26 February 2020 and reported the first death by COVID-19 on 29 February 2020. On 13 March 2020, President Donald Trump declared national emergency by opening federal funding up to 50 billion U.S. dollars. Though restrictions taken by CDC, Coronavirus has spread in 50 states on 17 March 2020. NY City declared U.S. as the epicenter of the disaster on 20 March 2020 (Schumaker, 2020). To protect U.S. citizens over the world, U.S. Department of State is taking decisive actions such as informing citizens, protecting homeland, increasing health capacity for potential new outbreaks, building partnerships and engaging with them, global aid and promoting transparency (U.S. Department of State, 2020). Epicenter of COVID-19 changes during the global crisis just as response and measures taken by the countries. Responses and measures also involve sustainability of education.

CDC has announced interim guidance for schools and programs regarding administrators. By interim guidance, it is intended to prevent transmission of COVID-19 within facilities and schools at district level. The guidance includes two choices to be made by local education authorities regarding risk of COVID-19. If there is no risk for community spread, teachers and administrators are required to take several measures such as planning for preventive actions, developing information sharing systems, teaching hygiene practices and motivating to apply, following procedures for cleaning school, monitoring attendance of students to the classes, postponing events, allowing stakeholders to stay at home against sickness, creating plans for contacting with school community and reviewing CDC guidance (CDC, 2020a).

In coordination with local health authorities, schools are thought to have an important role on preventing the spread COVID-19. Therefore, according to CDC, schools should take measures for COVID-19 outbreak by determining appropriate strategy. If an infected person has been witnessed within a school building, CDC recommends several procedures such as contacting with local health authorities, dismissing students and personnel for 
2-5 days, communicating with all stakeholders during dismissal process, disinfecting school, making decision on extension of dismissal and applying strategies for continue of education. Distance learning strategies should be encouraged for teaching staff and learners. E-learning plans and transition to online courses from face-to-face learning should be taken into consideration as appropriate as possible. Decisions regarding implementing aforementioned strategies should be made coordinated with local health authorities (CDC, 2020a). To this end, schools are responsible for implementing decisions autonomously based on the conditions.

Higher education institutions (HEI) also play an important role on slowing down spreading, and protecting public, students and staff to ensure creating healthy teaching contexts. CDC (2020b) prepared a guidance organized according to the level of community transmission:

1. Preparation phase involves if there is no community transmission.

2. Moderate level of community transmission

3. Substantial community transmission

Beside guidance, implementing strategies regarding social distance, cancellation of activities, and so on is applied after consulting and in collaboration with local health authorities. HEIs are supposed to coordinate with health officials to spread knowledge. HEI administrators are supposed to coordinate with local health authorities who determine the action with HEI administrators in case of infection. Those actions include cancellation of classes, club meetings, social events and sports events. Beside cancellation, discouraging stakeholders from socializing and gatherings are also taken into consideration. Moreover, guidance includes confidentiality of the students in case of COVID-19 which is required by Americans with Disabilities Act and the Family Education Rights and Privacy Act. To prevent COVID19 exposure, dismissal decisions regarding students are given and disinfection procedures are applied as specified in emergency operations plan (CDC, 2020b).

Preparation stage for COVID-19 includes reviewing and updating emergency plans, making plans for accurate dissemination of information, practicing hygiene procedures, monitoring students not only on the campus but also off the campus, cancellation of meetings and events. In case of a confirmed case, ensuring continuity of education and research activity is needed to be taken into consideration. Safety is the priority while distance 
learning and research plans are implemented. Online communication and education platforms are encouraged to use for teaching staff and students. HEIs have authority on determining the transition procedure for online learning from face-to-face learning, overcoming problems regarding technical issues, and increasing the number of students for enrolling into online classes. For students infected, HEI administrators have right to move the student to a temporary on campus or off campus house. Self-quarantine and monitoring procedures are also applied for close contacts. There are also measures taken in case of a moderate level of community transmission covering additional strategies to be implemented such as being in coordination with local health authorities, applying social distance procedures, accommodation of students and staff and dissemination of information through credited channels (CDC, 2020b).

\section{Educational policy implementations in Italy}

Italy announced first positive results for COVID-19 on 31 January 2020 (ANSA, 2020). The first Italian citizen infected was a 38-year-old man in Lombardy on 21 February 2020. Tracing process by the local authorities regarding origin of the infection remains inconclusive. Less than a week, the number of cases climbed up dramatically resulting unexpected consequences (Pucciarelli and Rancati, 2020). More cases have been reported by regions and autonomous provinces of northern Italy. Concerning that preparedness and containment procedures are unidentified, decentralization is seemed to be a disadvantage for Italy (Carinci, 2020). COVID-19 is a national health issue, but autonomous provinces of Italy are supposed to cope with local health issues. Mismanagement of the process, uncertainty of the health protocols and inconsistent measures such as dismissal of schools, cancellation of sports and social events taken by the local authorities of Italy lead to worsen the situation (La Stampa, 2020). Autonomous provinces of Italy have different practices and procedures on governance of health. Lack of homogeneity between different regions of Italy may have caused the spread of infection due to different isolation procedures. Moreover, dissemination of information is needed between regions. Tracing infected people and receiving information about different treatment procedures across country may help slowing down the spread of outbreak (Carinci, 2020). 
Preparedness for an outbreak regarding healthcare and education is considered important. Italy's preparedness regarding education is also questioned. ITCILO (2020) states that when the pandemic emerged, International Training Centre was not fully prepared. Innovation such as distance learning, self-guided online courses, webinars and assessments seem to be the solution of pandemic. Transition to online platforms is seen as a requirement for educational authorities of Italy (Ministry of Education, 2020). Providing online resources and equal online learning opportunities are the first goals determined by the ITCILO (2020). Putting online sources into practice and transition to online classes from face-to-face is the second stage of preparation (ITCILO, 2020). Moreover, ITCILO (2020) determined several routines as response to COVID-19. First routine is mobilizing digital taskforce which is assembled to unsure the sustainability of online education platforms. Second routine is transition of courses to online. Through ecampus, courses which are conducted face-to-face are adapted to online. Thirdly, training teachers for e-campus courses is considered important. Due to decrease in active engagement of students in online courses, teachers are trained to foster online learning. Fourthly, teaching methods are needed to be improved to enhance the learning of each student. Finally, adjusting to online education and home-office working can be compelling in different ways. Resilience of teachers may be improved by having breaks, making reflections and flexibility of the education program.

Ministry of Education (2020) announced a report about operational indications for distance learning activities. According to the report, considering essentials of schools, professional and ethical responsibilities guide community to be educated precisely. To continue learning process, e-versions of the sources should be implemented. It is also considered important to involve online learning activities and social activities such as watching movies, listening to music, etc. Moreover, distance learning can be perceived as opportunity for interventions on common critical issues. One of the operational measures taken by the Ministry of Education (2020) is to create a task force by the administration. Aim of this measure is to answer frequently asked questions about procedures and enhancing the effectiveness of the online classes. Gifted education institutions are also taken into consideration by this aim in terms of using information and communication technologies in teaching. 
Ministry of Education (2020) addresses distance education in different ways such as privacy, online educational activities, pupils with disabilities, students with special and special non-certified educational needs and the evaluation of distance learning activities. Education institutions are not supposed to request personal information of students during online education registration or process. On the other hand, education institutions are required to inform stakeholders to ensure safety of personal data in a lawful and transparent way for legitimate, explicit and specific purposes. Moreover, online educational activities are suggested to be reviewed by the local education institutions during pandemic in terms of redetermining the objectives and needs. Through determining objectives and needs, teachers have authority to manage teaching activities, materials and interaction with students. Management of education autonomously through teachers gives a chance to administrators to monitor ongoing process. Additionally, coordination of teachers and the interaction between them can be ensured through the procedure. Digital task force which is considered as one of the stakeholders also support learning process through implementing innovative strategies in context of distant learning (Ministry of Education, 2020).

Different adjustments are made for different levels of education. For the kindergarten, teachers need to develop activities in collaboration with families to contact directly (in a remote way). Beside subsequent level of education, for primary schools, excessive stay in front of screen should be avoided. At this level, autonomous learning activities should be carried out base on students' skills. For secondary schools, it is important to make connection between proposals of different teachers and students are needed to avoid excessive weight of the online commitment by changing virtual classes autonomously. Laboratory uses are postponed during online classes by encouraging teachers to prepare lesson plans covering theoretical contents. However, digital task force provides digital laboratories where students can practice on simulations. Moreover, inclusive education is also taken into consideration through referencing individualized education. To ensure equal opportunities for distance education, each pupil with disabilities is considered as the object of educational care by teacher and community. Pupils with different disabilities need different interventions based on educational planning. Strategies for students with special and special non-certi- 
fied educational needs are also implemented such as providing technological equipment, loan for use, special teaching aids, etc. A credited channel to communicate is also activated to inform about needs of students in ministerial portal. Transparency and legislation is considered for educational procedures and provided by evaluation activities. Evaluation process also have a role of enhancement and covers consolidations, research, and indications to proceed insights (Ministry of Education, 2020).

\section{Discussion, Conclusion and Recommendations}

Education policies implemented by countries differ in several ways. Crisis management skills of administrators and practitioners may help decrease the negative effect of COVID-19 Pandemic. The current study indicates that both educational policies and implementations in China, USA and Italy during the pandemic align with crisis management process proposed by Pearson and Clair (1998).

\section{Environmental context}

It is reported that there is a significant relationship between executive mindset and cultures of the executives' organizations (Bennis and Nanus, 1985; Martin, 1992). Similarly, organizational culture may impact executives' abilities on crisis management (Shapira, 1995). In China, the administrative structure is more centralized while in USA and Italy educational institutions are more autonomous depending on decentralization. Interaction among stakeholders enhances ability to manage crisis and persist regular procedures of the organization (Mitroff, Mason and Pearson, 1994). USA has adopted an understanding that schools and higher education institutions have the autonomy to take decisions under different conditions and educational institutions take an active role in preventing the spread of infection (CDC, 2020a), which implies a cooperation between the government and educational institutions. However, China has developed reactive policies toward COVID-19. One of the reasons for this may be the fact that China is the first country where the infection was emerged and spread rapidly. To prevent spreading, proactive policies may be undertaken by Chinese government through participation of stakeholders. Weick (1988) states that participation and coordination of stakeholders expand their perception so that they can seize opportunities and preparations for containment of crisis. 


\section{Awareness and preparations for the pandemic}

Pearson and Clair (1998) suggest institutionalized practices and regulations beside attention to crisis management and adoption of preparations for enhanced crisis management. Countries has been forced by COVID-19 outbreak to respond immediately to educational needs and they differentiated in policy making process during the pandemic. From the very beginning of the pandemic, China has developed a policy called Suspending Classes Without Stopping Learning (Zhang et. al., 2020) and implementation plan with five phases ranging from internet connection to teacher education. Technology facilitates smoothness for implementing policies. Pauchant and Douville (1994) refers technology as a tool for management of procedures, policies, practices and routines. To this end, by focusing on issues such as internet connection, time differences and use of TV channels, China has aimed equality on providing education for all students. Resources, content, supervision, workload, feedback, technical support, and instructional strategies are addressed systematically in terms of putting the plan into practice (Education and Technology Department, 2020). On the other hand, USA has more focused on preventing the spread of infection and developed school decisions on how to act in case of no community spread and minimal to moderate or substantial community spread. Pearson and Clair (1998) argues that technological-structure perspective may provide great advances on crisis. One of the actions that can be taken by schools and higher education institutions is to maintain educational activities through online education process (CDC, 2020a; 2020b). Online facilities may also serve as a strategic tool for organizations during crisis (Perry, Taylor and Doerfel, 2003). Similarly, Italy, where the infection has spread rapidly, may be considered unprepared (ITCILO, 2020); however, Italy has regarded transition to e-learning as a requirement and aimed to create equal opportunities for all students including students with special needs from kindergarten to high schools with facilities including digital labs.

Professional development for in-service teachers through online is also important (Avgerinou and Moros, 2020) to facilitate transition from face-toface to online learning (Ministry of Education, 2020). It can be concluded that Chinese government has determined and implemented policies in a systematic way while USA has behaved proactively on spreading through 
educational institutions as suggested by Thomsen (1995) who states that it is better to use online systems to shift from reactive policies to proactive policies.

\section{Individual-collective reactions and planned-ad hoc response}

Seeger, Sellnow, and Ulmer (2001) points out that success of crisis management depends on two factors: nature of the relationship between organization and stakeholders and understanding of organization regarding how stakeholders behave in times of crisis. It is evident that China, USA, and Italy have acted to respond educational needs of citizens through different policies during pandemic collectively. China is considered to take systematic actions from developing policies to implementation plans inclusively. USA offers distance education for preventing the spread of infection in collaboration with schools and HEIs. Italy also implements plans to sustain education through online platforms. It is also indicated that all of the three countries respond to pandemic in coordination with the stakeholders such as teachers, local health authorities, technical support units and administrators. Pearson and Clair (1998) state that effective containment of crisis depends on building alliances, achieving coordination, and sharing accurate information. Coombs (1999) notes that organizations are often unprepared for management of crisis, gathering information and dissemination of tasks. Regarding information dissemination, a two-fold flow has been encouraged by the governments of the countries. In this case, not only the instructions stated by governments but also the feedbacks taken from the schools are equally important for sustaining education during pandemic.

\section{Outcomes}

Mitroff and Alpaslan (2003) reported positive and significant correlation between successful outcomes of crisis management and proactive crisis management. Moreover, early detection of warning signals, minimal downtime, and effective damage control are supposed to result in successful crisis management (Pearson and Clair, 1998). Since the pandemic has not been under control yet, the outcomes of the educational policies and implementations are not currently visible. Success or failure of the policies will be determined by the dynamics emerging from the implementation stage, rate of spread, 
implementing proactive policies, supervision and monitoring of the policy implementations and coping with the technical and educational obstacles during the pandemic.

Current study seeks to present educational policies and implementations of the three countries from different continents during the pandemic. Either prepared or unprepared, all three countries are struggling to put the educational policies into practice mostly through online education. The purpose of the countries is to both sustain education and prevent the spread of infection. The results of the policies will be evident in the future according to the course of pandemic. Some implications can be inferred from the study in terms of implementing online education and educational policies, and further research.

1. Online education should be accessible for all students from kindergarten to higher education including students with special needs through internet or TV channels. Therefore, firstly internet infrastructure should be enhanced and provided for all students. Secondly, access to digital resources should be ensured equally. Lastly, the problems regarding internet connection should be closely monitored and authorities should develop instant solutions.

2. Flexible programs should be provided for students by considering their psychological well-being, educational needs, and interest. The negative side effects of the pandemic should be minimized by offering flexible and entertaining contents.

3. Online pedagogical framework should be constructed rigorously. Pedagogical strategies, contents and assessment and evaluation methods should be selected to meet teachers' and students' needs.

4. Empowering teachers should be another consideration. Teachers should be encouraged and supported about the use of online education. Teacher empowerment can be ensured through online seminars and webinars in the context of in-service teacher education programs.

5. Regarding education policies, sustainability of education should be prioritized. To this end, flexible plans should implement by considering the course of pandemic. Thus, teachers' and students' concerns and educational needs should be taken into consideration. There should be an alignment between online learning opportunities and assessment methods. 
6. To implement policies successfully, collaboration and cooperation among different levels of authorities and schools should be supported. To this end, some committees consisting of experts in education, health, technology and so forth should be established in both national and local levels.

7. Further research should focus on the process of educational policy implementations such as difficulties and coping with them, and effects of pandemic on students and teachers in terms of intellectual and psychological conditions.

\section{Kaynakça / References}

ANSA. (2020). Two Coronavirus cases found in Italy. Retrieved on 12 March 2020 from http://www.ansa.it/english/news/general news/2020/01/31/two-coronaviruscases-found-in-italy 981d57c5-67b9-4043-95d5-f6bd47e389df.html

Avgerinou, M. D. and Moros, S. E. (2020). The 5-phase process as a balancing act during times of disruption: Transitioning to virtual teaching at an international JK-5 school. In R. E. Ferdig, E. Baumgartner, R. Hartshorne, R. Kaplan-Rakowski \& C. Mouza (eds), (2020). Teaching, technology, and teacher education during the COVID-19 pandemic: Stories from the field. Association for the Advancement of Computing in Education (AACE). Retrieved on 15 June 2020 from https://www.learntechlib.org/p/216903/

Bennis, W., and Nanus, B. (1985). Leaders: The strategies for taking charge. New York: Harper-Perennial.

Carinci, F. (2020). Covid-19: Preparedness, decentralisation, and the hunt for patient zero. BMJ, 368. doi: https://doi.org/10.1136/bmj.m799

CDC. (2020a). Plan, prepare, and respond to Coronavirus disease 2019 (COVID-19). Retrieved on 14 April 2020 from https://www.cdc.gov/coronavirus/2019-ncov/community/schools-childcare/guidance-for-schools.html

CDC. (2020b). Plan, prepare, and respond to Coronavirus disease 2019 (COVID-19). Retrieved on 14 April 2020 from https://www.cdc.gov/coronavirus/2019ncov/community/guidance-ihe-response.html

Coombs, W. T. (1999). Ongoing crisis communication: Planning, managing and responding. Thousand Oaks, CA: Sage. 
Education and Technology Department. (2020). Notice of the office of the leading group of the ministry of education on the response to the epidemic situation of new Coronavirus infection on the support of education and teaching with informatization during the epidemic prevention and control. Retrieved on 11 March 2020 from http://www.moe.gov.cn/srcsite/A16/s3342/202002/t20200214 421005.html

Herdman, E.A. (2006). Derleme makale yazımında, konferans ve bildiri sunumu hazırlamada pratik bilgiler. Hemşirelikte Eğitim ve Araştırma Dergisi, 3(1), 2-4.

ITCILO. (2020). On the un campus in Italy, learning continues despite COVID-19: Five ways we are transitioning online. Retrieved on 11 April 2020 from https://www.itcilo.org/e-learning-covid-19

La Stampa. (2020). Regioni sotto accusa. conte: "Toglieremo i poteri". La replica dalla Lombardia: "Purtroppo abbiamo seguito il governo. Retrieved on 08 June 2020 from https:/www.lastampa.it/cronaca/2020/02/25/news/regioni-sotto-accusaconte-toglieremo-i-poteri-la-replica-dalla-lombardiapurtroppo-abbiamo-seguito-il-governo-1.38515045

Martin, J. (1992). Cultures in organizations: Three perspectives. New York: Oxford University Press.

McAleer, M. (2020). Prevention is better than the cure: Risk management of COVID-19. Journal of Risk and Financial Management, 13(3). doi: https://doi.org/10.3390/jrfm13030046

Ministry of Education of the People's Republic of China. (2020a). Guidance on the organization and management of online teaching in colleges and universities during the epidemic prevention and control period. retrieved on 14 March 2020 from http://www.moe.gov.cn/srcsite/A08/s7056/202002/t20200205 418138.html

Ministry of Education of the People's Republic of China. (2020b). Relevant person in charge of the ministry of education answered reporters' questions on the postponement of the "Suspending Classes Without Stopping Learning" in Primary and Secondary Schools". Retrieved on 14 March 2020 from http://www.moe.gov.cn/jyb_xwfb/s271/202002/t20200211_420109.html

Ministry of Education. (2020). Dipartimento per il sistema educativo di istruzione e di formazione. Retrieved on 1 April 2020 from https:/www.miur.gov.it/documents/20182/0/Nota+prot.+388+del+17+marzo+2020.pdf/d6acc6a2-1505-9439a9b4-735942369994?version=1.0\& $\mathrm{t}=1584474278499$

Mitroff, I. I., and Alpaslan, C. M. (2003). Preparing for evil. Harvard Business Review, 81(4),109-115. 
Mitroff, I. I., Alpaslan, C. M., and Green, S. E. (2004). Crises as Ill-structured messes: Philosophical issues of crisis management. The International Studies Review, 6(2), 175-182.

Mitroff, I. I., Mason, R. O., and Pearson, C. M. (1994). Framebreak. San Francisco: JosseyBass

OSHA. (2020). Occupational safety and health administration. Retrieved on 14 March 2020 from https://www.osha.gov/SLTC/covid-19/

Patrinos, H. A., and Shmis, T. (2020). Can technology help mitigate the impact of COVID-19 on education systems in Europe and Central Asia?. Retrieved on 14 March 2020 from https://blogs.worldbank.org/europeandcentralasia/can-technologyhelp-mitigate-impact-covid-19-education-systems-europe-and

Pauchant, T. C., and Douville, R. (1994). Recent research in crisis management: A study of 24 authors' publications from 1986 to 1991. Industrial and Environmental Crisis Quarterly, 7, 43-61.

Pearson, C. M., and Clair, J. A. (1998). Reframing crisis management. Academy of Management Review, 23(1), 59-76.

Perry, D. C., Taylor, M., and Doerfel, M. L. (2003). Internet-based communication in crisis management. Management Communication Quarterly, 17(2), 206-232.

Pucciarelli, M., and Rancati, M. (2020). Coronavirus, tutti gli spostamenti di Mattia, il 38enne contagiato di Codogno. La Repubblica, Retrieved on 21 March 2020 from https://www.repubblica.it/cronaca/2020/02/22/news/il_contagiato249206473/

Reuters. (2020). Locked-down no longer, China's Hubei begins return to normal. Retrieved on 18 June 2020 from https:/www.reuters.com/article/us-health-coronaviruschina-toll/locked-down-no-longer-chinas-hubei-begins-return-to-normalidUSKBN21C01A

Schumaker, E. (2020). Timeline: How Coronavirus got started. ABC News, Retrieved on 10 June 2020 from https://abcnews.go.com/Health/timeline-coronavirusstarted/story?id=69435165

Seeger, M. W., Sellnow, T. L., and Ulmer, R. R. (2001). Public relations and crisis communication: Organizing and chaos. In R. L. Heath (ed), Handbook of public relations (p. 155-166). Thousand Oaks, CA: Sage.

Shan-Lu, L., and Saif, L. (2020). Emerging viruses without borders: The Wuhan coronavirus. Viruses, 12(2). doi: https://doi.org/10.3390/v12020130

Shapira, Z. (1995). Risk taking: A managerial perspective. New York: Russell Sage Foundation 
The People's Government of Zhejiang Province. (2020). Zhejiang's guidance issued for the implementation of online education during the delayed start of primary and middle schools. Retrieved on 24 March 2020 from http://www.zj.gov.cn/art/2020/2/6/art_1654331_41948673.html

Thomsen, S. R. (1995). Using online databases in corporate issues management. Public Relations Review, 21, 103-122.

U.S. Department of State. (2020). Coronazirus disease 2019 (COVID-19). Retrieved on 19 March 2020 from https://www.state.gov/coronavirus/

UNESCO. (2020). How is China ensuring learning when classes are disrupted by coronavirus?. Retrieved on 20 June 2020 from https://en.unesco.org/news/how-china-ensuring-learning-when-classes-are-disrupted-coronavirus

Weick, K. E. (1988). Enacted sensemaking in crisis situations. Journal of Management Studies, 25, 305-317.

Wuhan Municipal Health Commission. (2019). Wuhan Municipal Health Commission's briefing on the current pneumonia epidemic situation in our city. Retrieved on 18 March $2020 \quad$ from http://wjw.wuhan.gov.cn/front/web/showDetail/2019123108989

Yue, X. G., Shao, X. F., Li, R. Y. M., Crabbe, M. J. C., Mi, L., Hu, S., Baker, J. S., and Liang, G. (2020). Risk management analysis for novel Coronavirus in Wuhan, China. Journal of Risk and Financial Management, 13(2). doi: https://doi.org/10.3390/jrfm13020022

Zhang, W., Wang, Y., Yang, L., and Wang, C. (2020). Suspending Classes Without Stopping Learning: China's education emergency management policy in the COVID-19 outbreak. Journal of Risk and Financial Management, 13(3). doi: https://doi.org/10.3390/jrfm13030055

Zhaohui, W. (2020). How a top Chinese university is responding to Coronavirus. World Economic Forum, Retrieved on 18 June 2020 from https://www.weforum.org/agenda/2020/03/coronavirus-china-the-challenges-of-online-learning-for-universities/

\section{Kaynakça Bilgisi / Citation Information}

Karsantık, I. (2021). Crisis management on education policies during Covid-19: The case of China, USA and Italy. OPUS-International Journal of Society Researches, 17(Pandemi Özel Say1sı), 3128-3147. DOI: $10.26466 /$ opus.826383 